\title{
Synthesis Gas Production via the Solar Partial Oxidation of Methane-Ceria Redox Cycle: Conversion, Selectivity, and Efficiency
}

\author{
Peter T. Krenzke, Jesse R. Fosheim, Jingyang Zheng, Jane H. Davidson ${ }^{1}$ \\ Department of Mechanical Engineering, University of Minnesota - Twin Cities
}

\begin{abstract}
The importance of methane conversion, syngas selectivity, and oxidizer conversion for efficient syngas production by the partial oxidation of methane using a metal oxide redox cycle is quantified. The operating conditions which enable high conversion of methane to syngas over cerium oxide and conversion of carbon dioxide to carbon monoxide in the subsequent oxidation reaction are identified experimentally. The parametric study considers operating temperatures of 900 and $1000^{\circ} \mathrm{C}$ and methane flow rates from 1 to $15 \mathrm{~mL} \mathrm{~min}^{-1} \mathrm{~g}^{-1}$ in a fixed bed of porous ceria particles. The reduced ceria is reoxidized in a flow of $10 \mathrm{~mL} \mathrm{~min}^{-1} \mathrm{~g}^{-1} \mathrm{CO}_{2}$ to produce CO. A trade-off of achieving high methane conversion is observed. For example, at $1000^{\circ} \mathrm{C}$, the cycleaveraged methane conversion increases from $13 \%$ for reduction in $15 \mathrm{~mL} \mathrm{~min}^{-1} \mathrm{~g}^{-1}$ to $60 \%$ in $1 \mathrm{~mL} \mathrm{~min}^{-1} \mathrm{~g}^{-1}$. For the same change in methane flow rate, the cycle-averaged selectivities decrease from $78 \%$ to $39 \%$ (CO) and $77 \%$ to $40 \%\left(\mathrm{H}_{2}\right)$ and the oxidizer conversion decreases from $93 \%$ to $48 \%$. The maximum projected solar-to-fuel thermal efficiency is $27 \%$ for cycling at $1000^{\circ} \mathrm{C}$ with reduction in $5 \mathrm{~mL} \mathrm{~min}^{-1} \mathrm{~g}^{-1}$ methane.
\end{abstract}

Keywords: ceria; solar; hydrogen; carbon monoxide; conversion; selectivity

\footnotetext{
${ }^{1}$ Corresponding author email: jhd@me.umn.edu
} 


\section{Introduction}

Syngas and its components, carbon monoxide and hydrogen, are building blocks for producing prominent chemicals such as liquid fuels and ammonia. In the present study we consider the combination of two attractive processes to produce syngas. The first process is the partial oxidation of methane (R1).

$$
\mathrm{CH}_{4}+1 / 2 \mathrm{O}_{2} \rightarrow \mathrm{CO}+2 \mathrm{H}_{2}
$$

Partial oxidation of methane is an excellent match for production of methanol or Fischer-Tropsch liquid fuels because the $\mathrm{H}_{2} / \mathrm{CO}$ ratio of the syngas is 2:1. The second process is water and/or carbon dioxide splitting via a metal oxide redox cycle, which stores solar energy in chemical form by utilizing concentrated solar process heat to drive the reverse combustion reactions.

In the combined approach considered in the present study, the partial oxidation of methane and solar water or carbon dioxide splitting are coupled by the cerium dioxide (ceria) redox cycle, which consists of two heterogeneous reactions. In the ceria reduction reaction (R2), methane reacts with oxygen released by ceria to produce syngas with $\mathrm{H}_{2} / \mathrm{CO}=2$.

$$
\mathrm{CH}_{4}+\frac{1}{\Delta \delta} \mathrm{CeO}_{2-\delta_{0 X}} \rightarrow 2 \mathrm{H}_{2}+\mathrm{CO}+\frac{1}{\Delta \delta} \mathrm{CeO}_{2-\delta_{\mathrm{RD}}}
$$

This step increases the nonstoichiometry of the ceria to a reduced state, $\delta_{\mathrm{RD}}$. In the ceria oxidation reactions, steam (R3a) and/or carbon dioxide (R3b) react with the reduced ceria to produce hydrogen and/or carbon monoxide, and the ceria returns to an oxidized state, $\delta_{\mathrm{OX}}<\delta_{\mathrm{RD}}$. 


$$
\begin{gathered}
\mathrm{H}_{2} \mathrm{O}+\frac{1}{\Delta \delta} \mathrm{CeO}_{2-\delta_{\mathrm{RD}}} \rightarrow \mathrm{H}_{2}+\frac{1}{\Delta \delta} \mathrm{CeO}_{2-\delta_{0 \mathrm{X}}} \\
\mathrm{CO}_{2}+\frac{1}{\Delta \delta} \mathrm{CeO}_{2-\delta_{\mathrm{RD}}} \rightarrow \mathrm{CO}+\frac{1}{\Delta \delta} \mathrm{CeO}_{2-\delta_{\delta X}}
\end{gathered}
$$

The cycle is endothermic for both $\mathrm{H}_{2} \mathrm{O}$ and $\mathrm{CO}_{2}$ splitting. As a consequence, solar energy is stored in the products and the syngas has a higher energy content than the methane feedstock. The energetic upgrade factor,

$$
\mathrm{U}=\frac{\sum_{\mathrm{i}} \mathrm{n}_{\mathrm{i}, \mathrm{OUT}} \mathrm{HHV}_{\mathrm{i}}}{\sum_{\mathrm{i}} \mathrm{n}_{\mathrm{i}, \mathrm{IN}} H H V_{\mathrm{i}}}
$$

is the ratio of the total heating value of the products of the cycle to the heating value of the methane feedstock. With complete conversion of methane to synthesis gas and oxidizer to fuel, the energetic upgrade factor is $128 \%$ for both $\mathrm{H}_{2} \mathrm{O}$ and $\mathrm{CO}_{2}$ splitting. Because there is an energetic upgrade, combusting the products of the cycle emits $22 \%$ less net $\mathrm{CO}_{2}$ than combusting the methane feedstock. Depending on the oxidizer, the cycle produces the same net products as steam-reforming or dry-reforming of methane. Unlike the reforming reactions, the products of reactions R2 and R3 are in two separate streams: one containing syngas and the other pure hydrogen (R3a) or carbon monoxide (R3b). The separate gas streams are valuable individually or may be mixed to tune the $\mathrm{H}_{2} / \mathrm{CO}$ ratio, making the process amenable to synthesis of a wider range of products than either steam- or dry-reforming of methane.

In evaluating the promise of nascent solar thermochemical processes, it is common to use efficiency as a surrogate for cost. Using an equilibrium model and assuming isothermal operation at $950^{\circ} \mathrm{C}$, Krenzke and Davidson predict the solar-to-fuel thermal efficiency of the partial oxidation of methane-ceria redox cycle could reach $40 \%$ for $\mathrm{H}_{2} \mathrm{O}$ and $39 \%$ for $\mathrm{CO}_{2}$ splitting [1]. Key assumptions in the prior analysis are that the two reactions proceed to equilibrium states in 
mixed flow reactors and oxygen is released from ceria in reaction R2 to provide $\mathrm{CH}_{4} / \mathrm{O}_{2}=2$ required for the partial oxidation of methane (R1).

The primary challenges to reaching the predicted efficiency of the partial oxidation of methane-ceria redox cycle are achieving $\mathrm{CH}_{4} / \mathrm{O}_{2}=2$, high methane conversion, and high selectivity toward syngas in the reduction reaction (R2) and achieving high conversion of oxidizer to fuel in the oxidation reaction (R3). According to chemical thermodynamics, both the complete conversion of methane and high syngas selectivity (>97\%) are ensured by operating reaction R2 with $\mathrm{CH}_{4} / \mathrm{O}_{2}=2$ at or above $900^{\circ} \mathrm{C}$. High equilibrium oxidizer conversion (>80\%) in the subsequent oxidation reaction is ensured by limiting oxidation to nonstoichiometries of $\delta>0.05$. For systems that do not achieve the equilibrium product distribution or for which $\mathrm{CH}_{4} / \mathrm{O}_{2}>2$, unconverted methane and oxidizer may constitute a significant additional heating requirement. For syngas selectivities less than $100 \%$, which are promoted by $\mathrm{CH}_{4} / \mathrm{O}_{2}<2$, water and carbon dioxide formed by the reaction between methane and ceria also increase the required energy input for the cycle.

Prior experimental studies of the partial oxidation of methane over cerium-based oxides provide comparison of methane conversion and selectivity toward syngas for mixed ceria-ferrite [2-7] or ceria-zirconia [8-10] oxides. $\mathrm{Li}$ et al. found increasing iron content in $\mathrm{Ce}_{1-\mathrm{x}} \mathrm{Fe}_{\mathrm{x}} \mathrm{O}_{2-\delta}$ $(\mathrm{x}=0-0.5)$ increases the methane conversion at $850^{\circ} \mathrm{C}$, but decreases the selectivity toward syngas [3]. The morphology of the metal oxide is also known to impact conversion and selectivity. For reduction of macroporous $\mathrm{Ce}_{0.8} \mathrm{Zr}_{0.2} \mathrm{O}_{2}$ at $800^{\circ} \mathrm{C}$ in methane, Zheng et al. attribute a decrease in methane conversion and an increase in syngas selectivity to the collapse of the macroporous architecture and loss in surface area with increasing calcination temperature [10]. Zhu et al. observed that increasing the reaction temperature $\left(800-900^{\circ} \mathrm{C}\right)$ increases both methane 
conversion and syngas selectivity for $\mathrm{Ce}_{0.5} \mathrm{Fe}_{0.5} \mathrm{O}_{2-\delta}$ [5]. High methane conversion (77\%) and high selectivity toward hydrogen (87\%) and carbon monoxide (86\%) were obtained at $900^{\circ} \mathrm{C}$ with a methane flow rate of $5.6 \mathrm{~mL} \mathrm{~min}^{-1} \mathrm{~g}^{-1}[5]$.

Isothermal cycling data for undoped ceria are limited to temperatures up to $850^{\circ} \mathrm{C}$. Undoped ceria is particularly attractive for the solar process because it has been shown to enable high oxidizer conversion at $500^{\circ} \mathrm{C}$ [11]. Repeatable cycling with ceria is facilitated by limiting the nonstoichiometry below 0.2 to avoid carbon deposition [11,12]. In the prior work, high selectivity toward hydrogen (87\%) and carbon monoxide (92\%) but low methane conversion (24\%) were observed at $850^{\circ} \mathrm{C}$ [3]. Based on the improvement of conversion and selectivity with increasing temperature observed by $\mathrm{Zhu}$ et al. for $\mathrm{Ce}_{0.5} \mathrm{Fe}_{0.5} \mathrm{O}_{2-\delta}$ [5], higher temperatures are anticipated to favor improved methane conversion without sacrificing selectivity.

To determine the actual expected efficiency of the cycle, it is necessary to quantify the conversion of oxidizer $\left(\mathrm{H}_{2} \mathrm{O}\right.$ or $\left.\mathrm{CO}_{2}\right)$ to fuel. None of the prior work evaluated the partial oxidation of methane-ceria redox cycle using pure carbon dioxide or steam as the cycle would be operated commercially. The oxidant in the prior work was dilute oxygen $[3,4,6,7]$, dilute steam $[5,8,10-13]$ or dilute carbon dioxide $[11,12,14]$. We note that oxidation of ceria by oxygen or air results in an exothermic redox cycle and is not suitable for storing solar energy in chemical form. Studies of water and carbon dioxide splitting over ceria that target a ceria cycle with reduction in sweep gas or vacuum rather than methane have evaluated only a narrow nonstoichiometry range $\delta<0.06$ [15], or have also used dilute oxidizer [16-19].

In the present study we quantify the importance of methane conversion, syngas selectivity, and oxidizer conversion on the thermal efficiency of the solar-to-fuel conversion. Experimentally, we identify the conditions which enable high conversion of methane to syngas 
over ceria and conversion of carbon dioxide to carbon monoxide. In the experimental study, we examine the influences of operating temperature, methane flow rate, and nonstoichiometric state on the production of syngas from methane and fuel from oxidizer over ceria in a fixed bed reactor. Key results are conversion of methane and selectivity toward syngas in the reduction of ceria and the conversion of carbon dioxide to carbon monoxide in the oxidation of ceria.

\section{Efficiency Projections}

We define a commercially relevant solar-to-fuel thermal efficiency as the net gain in the heating value of the methane and product gas divided by the solar input to the thermochemical reactor plus the work requirements for separation of products and pumping.

$$
\eta=\frac{\sum_{\mathrm{i}} \mathrm{n}_{\mathrm{i}, \mathrm{OUT}} \mathrm{HHV}_{\mathrm{i}}-\sum_{\mathrm{i}} \mathrm{n}_{\mathrm{i}, \mathrm{IN}} \mathrm{HHV}_{\mathrm{i}}}{\mathrm{Q}_{\mathrm{SOL}}+\frac{\mathrm{W}_{\text {PARASITIC }}}{\eta_{\mathrm{S} \rightarrow \mathrm{E}}}}
$$

In the present study, the work requirements are based on commercial processes and are adjusted to account for an assumed 25\% efficiency for converting solar energy to electricity. The solar-tofuel efficiency is projected as a function of methane conversion and selectivity and oxidizer conversion using a first law analysis of a representative solar reactor. The energy balance is given by equation 6 .

$$
\mathrm{Q}_{\mathrm{SOL}}+\frac{\mathrm{W}_{\text {PARASITIC }}}{\eta_{\mathrm{S} \rightarrow \mathrm{E}}}=\mathrm{Q}_{\mathrm{RAD}}+\mathrm{Q}_{\mathrm{LOSS}}+\mathrm{Q}_{\mathrm{GAS}}+\frac{\mathrm{w}_{\Delta \mathrm{P}}}{\eta_{\mathrm{S} \rightarrow \mathrm{E}}}+\frac{\mathrm{w}_{\mathrm{SEP}}}{\eta_{\mathrm{S} \rightarrow \mathrm{E}}}
$$

The left hand side of equation 6 is the sum of the solar thermal input $\left(Q_{s o L}\right)$ and the solar thermal equivalent of the parasitic work (W $\mathrm{W}_{\text {PARASITIC }}$ ) required to produce one mole of fuel in the oxidation reaction $(\mathrm{R} 3)$. The solar process heat $\left(\mathrm{Q}_{\mathrm{sOL}}\right)$ is determined by the heat requirements on the right hand side, which include radiative emission losses $\left(\mathrm{Q}_{\mathrm{RAD}}\right)$, thermal losses to the ambient (QLoss), the chemical energy change and sensible heating of the gases $\left(\mathrm{Q}_{\mathrm{GAS}}\right)$. The work input ( $\mathrm{W}_{\text {PARASITIC }}$ ) is determined by the work requirements on the right hand side for pumping process 
gases $\left(W_{\triangle \mathrm{P}}\right)$ and separating products $\left(\mathrm{W}_{\mathrm{SEP}}\right)$. Each of the work terms is divided by the efficiency of conversion of solar energy to electricity.

Losses due to thermal emission from the solar cavity receiver and due to conductive losses through the insulated reactor to the ambient are independent of the conversions and selectivities attained in the chemical reactions.

$$
\begin{aligned}
Q_{\text {RAD }} & =\frac{\sigma T^{4}}{C I} Q_{S O L} \\
Q_{\text {LOSS }} & =0.05 Q_{S O L}
\end{aligned}
$$

Conductive losses are assumed equal to $5 \%$ of the solar input, consistent with predictions for commercial-scale solar reactors [20].

It is expedient to formulate the gas requirements in terms of conversions and selectivities. The amount of methane and oxidizer supplied are given by equations 9 and 10 .

$$
\begin{gathered}
\mathrm{n}_{\mathrm{CH}_{4}, \mathrm{IN}}=\frac{1}{\mathrm{X}_{\mathrm{CH}_{4}}\left(4-2 \mathrm{~S}_{\mathrm{H}_{2}}-\mathrm{S}_{\mathrm{CO}}\right)} \\
\mathrm{n}_{\mathrm{CO}_{2}, \mathrm{IN}}=\frac{1}{\mathrm{X}_{\mathrm{CO}_{2}}}
\end{gathered}
$$

The products are quantified by equations 11-15.

$$
\begin{gathered}
\mathrm{n}_{\mathrm{CH}_{4}, \text { OUT }}=\left(1-\mathrm{X}_{\mathrm{CH}_{4}}\right) \mathrm{n}_{\mathrm{CH}_{4}, \mathrm{IN}} \\
\mathrm{n}_{\mathrm{H}_{2}, \text { OUT }}=2 \mathrm{X}_{\mathrm{CH}_{4}} \mathrm{~S}_{\mathrm{H}_{2}} \mathrm{n}_{\mathrm{CH}_{4}, \mathrm{IN}} \\
\mathrm{n}_{\mathrm{H}_{2} \mathrm{O}, \text { OUT }}=2 \mathrm{X}_{\mathrm{CH}_{4}}\left(1-\mathrm{S}_{\mathrm{H}_{2}}\right) \mathrm{n}_{\mathrm{CH}_{4}, \mathrm{IN}} \\
\mathrm{n}_{\mathrm{CO}, \text { OUT }}=\mathrm{X}_{\mathrm{CH}_{4}} \mathrm{~S}_{\mathrm{CO}} \mathrm{n}_{\mathrm{CH}_{4}, \mathrm{IN}}+\mathrm{X}_{\mathrm{CO}_{2}} \mathrm{n}_{\mathrm{CO}_{2}, \mathrm{IN}} \\
\mathrm{n}_{\mathrm{CO}_{2}, \text { OUT }}=\mathrm{X}_{\mathrm{CH}_{4}}\left(1-\mathrm{S}_{\mathrm{CO}}\right) \mathrm{n}_{\mathrm{CH}_{4}, \mathrm{IN}}+\left(1-\mathrm{X}_{\mathrm{CO}_{2}}\right) \mathrm{n}_{\mathrm{CO}_{2}, \mathrm{IN}}
\end{gathered}
$$

The net enthalpy change of the gases accounts for sensible and chemical energy. 


$$
\mathrm{Q}_{\mathrm{GAS}}=\sum_{\mathrm{i}} \mathrm{n}_{\mathrm{i}, \mathrm{OUT}} \mathrm{h}_{\mathrm{i}}(\mathrm{T})-\sum_{\mathrm{i}} \mathrm{n}_{\mathrm{i}, \mathrm{IN}} \mathrm{h}_{\mathrm{i}}\left(\mathrm{T}_{\infty}\right)
$$

Summations are for all of the above species.

The work requirements for pumping the reactants and separation of the carbon monoxide produced from carbon dioxide in the oxidation reaction are given by equations 17 and 18.

$$
\begin{gathered}
\mathrm{W}_{\Delta \mathrm{P}}=\left(\mathrm{n}_{\mathrm{CH}_{4}, \mathrm{IN}}+\mathrm{n}_{\mathrm{CO}_{2}, \mathrm{IN}}\right) \mathrm{RT}_{\infty} \ln \left(\frac{\mathrm{p}_{\infty}+\Delta \mathrm{p}}{\mathrm{p}_{\infty}}\right) / \mathrm{\eta}_{\mathrm{P}} \\
\mathrm{W}_{\mathrm{SEP}}=\frac{1}{\mathrm{X}_{\mathrm{CO}_{2}}} \mathrm{RT}_{\infty}\left(\mathrm{X}_{\mathrm{CO}_{2}} \ln \left(\mathrm{X}_{\mathrm{CO}_{2}}\right)+\left(1-\mathrm{X}_{\mathrm{CO}_{2}}\right) \ln \left(1-\mathrm{X}_{\mathrm{CO}_{2}}\right)\right) / \eta_{\mathrm{SEP}}
\end{gathered}
$$

Conversion and selectivity are treated as free parameters to illustrate the impact of each on the solar-to-fuel efficiency. Projections of efficiency for measured values from the present experimental study are included in section 4.3. Assumed values used to project efficiencies are summarized in Table 1.

Table 1. Values of Fixed Parameters used for the Efficiency Projections in Figure 1 and section 4.3.

\begin{tabular}{|c|c|}
\hline Parameter & Value \\
\hline $\mathrm{C}$ & 1000 \\
\hline $\mathrm{p}_{\mathrm{SYS}}$ & $100 \mathrm{kPa}$ \\
\hline$\Delta \mathrm{p}^{\mathrm{a}}$ & $5 \mathrm{kPa}$ \\
\hline$\eta_{\mathrm{S} \rightarrow \mathrm{E}}[21]$ & 0.25 \\
\hline$\eta_{\mathrm{P}}[22]$ & 0.8 \\
\hline$\eta_{\mathrm{SEP}}[23]$ & 0.1 \\
\hline
\end{tabular}

${ }^{a}$ Taken as the largest measured pressure drop during experimental evaluation of R1 and R2.

Figure 1 shows predicted reactor efficiency as a function of methane conversion for operation of the cycle at $1000^{\circ} \mathrm{C}$. Efficiencies projected for operation at $900^{\circ} \mathrm{C}$ exhibit the same trends, but are higher due to decreased losses and gas heating requirements. The four curves on the plot show the impact of selectivity $\left(S_{\mathrm{H}_{2}}=S_{\mathrm{CO}}\right)$ and oxidizer conversion $\left(\mathrm{X}_{\mathrm{CO}_{2}}\right)$. The upper bound on efficiency is $54 \%$ for methane conversion and syngas selectivities of $X_{\mathrm{CH}_{4}}=S_{\mathrm{H}_{2}}=S_{C O}=1$ 
and an oxidizer conversion of $X_{\mathrm{CO}_{2}}=1$. Efficiency decreases with decreasing methane conversion, selectivity, and oxidizer conversion because of the increase in the quantity of gas that must be heated, pumped, and separated relative to the amount of syngas produced. The efficiency of an actual reactor will depend on the selectivities and conversions obtained in practice.

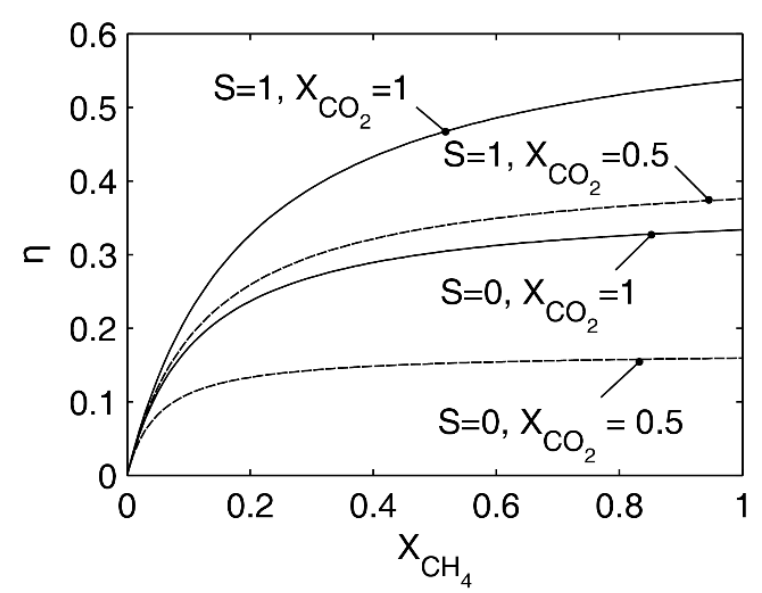

Figure 1. Efficiency as a function of methane conversion for cycling at ${ }^{1000}{ }^{\circ} \mathrm{C}$. The impacts of selectivity and oxidizer conversion are shown for a range of conditions.

\section{Experimental Method}

\subsection{Isothermal Redox Cycling}

To evaluate the impact of temperature and flow rate on the conversions and selectivities of methane to syngas and oxidizer to fuel that can be achieved in an isothermal fixed bed reactor, redox cycles were carried out at atmospheric pressure at 900 and $1000^{\circ} \mathrm{C}$. These temperatures coincide with the range identified in a prior thermodynamic analysis that provide complete methane conversion and syngas selectivity above $97 \%$ in reaction $\mathrm{R} 2$ and $80 \%$ conversion of $\mathrm{CO}_{2}$ to $\mathrm{CO}$ in reaction $\mathrm{R} 3$ [1]. Cycling at $1100^{\circ} \mathrm{C}$ was also attempted in preliminary experiments. However, significant and immediate carbon deposition was observed. Thus, $1000^{\circ} \mathrm{C}$ is near the practical upper limit for operation of the cycle. The influence of methane flow rate on conversion and syngas selectivity was explored for methane flow rates of $1,2.5,5,10$, and $15 \mathrm{~mL} \mathrm{~min}^{-1} \mathrm{~g}^{-1}$ 
with the ceria bed initialized by oxidation in $10 \mathrm{~mL} \mathrm{~min}^{-1} \mathrm{~g}^{-1} \mathrm{CO}_{2}$ for 25 minutes. Methane flow rates were selected to achieve measurable variation in methane conversion based on observations from preliminary experiments conducted over a larger range of flow rates than those reported. Preliminary experiments also identified reduction durations which avoid carbon deposition. The $\mathrm{CO}_{2}$ flow rate was selected to attain high oxidizer conversion. Reduction in $\mathrm{CH}_{4}$ (99.99\%) and oxidation in $\mathrm{CO}_{2}$ (99.99\%) were separated by an intermediate purge with argon (99.99\%) in order to measure the total product gas streams for each reaction. To initiate each experiment, several cycles were conducted with a methane flow rate of $15 \mathrm{~mL} \mathrm{~min}^{-1} \mathrm{~g}^{-1}$ until syngas production stabilized. The timing for these initial cycles was identical to those presented in the results section. A slight increase in syngas productivity was observed over the first few cycles. After the initial break-in period, three cycles were conducted at each condition to verify repeatability. Reduction gas production rates are shown for each cycle and calculated conversions and selectivities are shown for representative cycles in section 4.

\subsection{Reactive Substrate}

Cylindrical porous ceria particles, $4.7 \mathrm{~mm}$ diameter by $5 \mathrm{~mm}$ long, were formed from fibers using a proprietary molding process. A representative electron micrograph is shown in Figure 2. The mean diameter and length of the fibers, determined from analysis of multiple electron micrographs, are $6 \pm 1.6 \mu \mathrm{m}$ and $62 \pm 27 \mu \mathrm{m}$. The porosity is $81 \%$ and the specific surface area is $0.143 \mathrm{~m}^{2} / \mathrm{g}$ measured via mercury porosimetry and BET krypton adsorption. In a prior study considering the reduction of $3-5 \mathrm{~mm}$ microporous ceria particles using inert sweep gas, intraparticle heat and mass diffusion were sufficiently fast so as not to limit reaction rates [24]. For ceria reduction in methane, the partial oxidation reaction (R2) provides an oxygen sink that is capable of maintaining much lower oxygen partial pressure than is possible with inert sweep 
gas. Thus, the driving force for the surface reaction is substantially larger resulting in shorter time scales for the chemical reactions. To assess the impact of particle size, smaller particles of the same microstructure were obtained by crushing the cylindrical particles and then sieving to a 1-1.4 mm size range. Hereafter the smaller particles are referred to as $1 \mathrm{~mm}$ particles and the larger cylindrical particles as $5 \mathrm{~mm}$ particles.

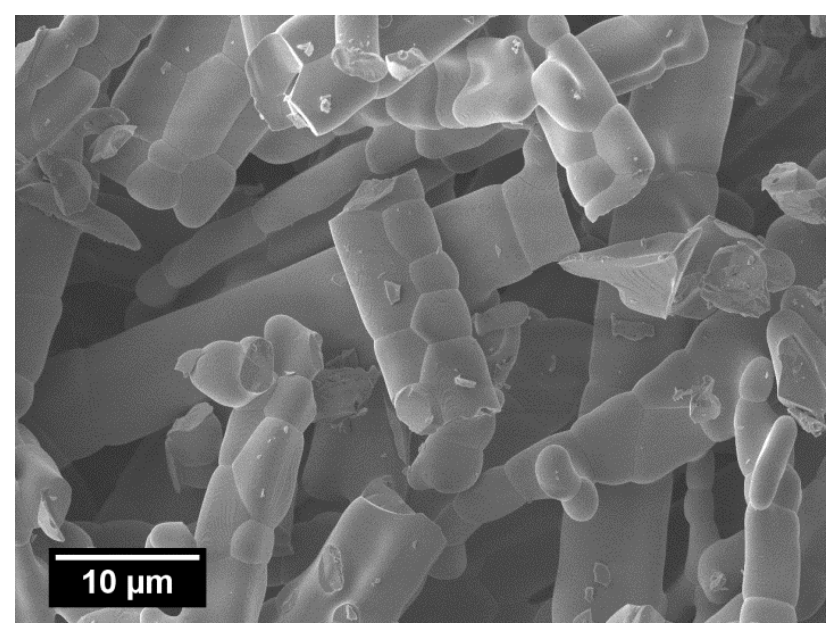

Figure 2. Electron micrograph of a fibrous ceria. Fiber diameters and lengths are $6 \pm 1.6 \mu \mathrm{m}$ and $62 \pm 27 \mu \mathrm{m}$.

\subsection{Apparatus}

The porous ceria particles, $1 \mathrm{~mm}$ or $5 \mathrm{~mm}$, were packed into a bed with a void fraction of $35 \%$. Figure 3 is a sketch of the apparatus. The particle bed was contained in a high-density, high-purity $12.7 \mathrm{~mm}$ o.d., $9.5 \mathrm{~mm}$ i.d. alumina tube. The alumina tube containing the particles was heated in an electric tube furnace. Alumina-sheathed chromel-alumel thermocouple probes were placed in contact with the upstream and downstream faces of the bed to monitor temperature and a pressure transducer $( \pm 0.1 \mathrm{kPa})$ was used to measure the gauge pressure upstream of the reactor. The spatial variation in temperature across the bed indicated by the thermocouples was less than $10^{\circ} \mathrm{C}$. Temporal variations in temperature, which are induced by the chemical reactions, were less than $8^{\circ} \mathrm{C}$. The pressure drop across the bed during $\mathrm{R} 1$ and $\mathrm{R} 2$ was less than $5 \mathrm{kPa}$. Gases were delivered using high accuracy ( $\pm 1 \%$ of reading) mass flow 
controllers. The outlet composition of the gas was measured with a Raman laser gas analyzer calibrated to measure nitrogen, oxygen, carbon dioxide, carbon monoxide, hydrogen, and methane volume concentrations to within $\pm 3 \%$ of the reading. The total outlet flow rate was determined using a reference flow of cryogenic-grade nitrogen (99.998\%).

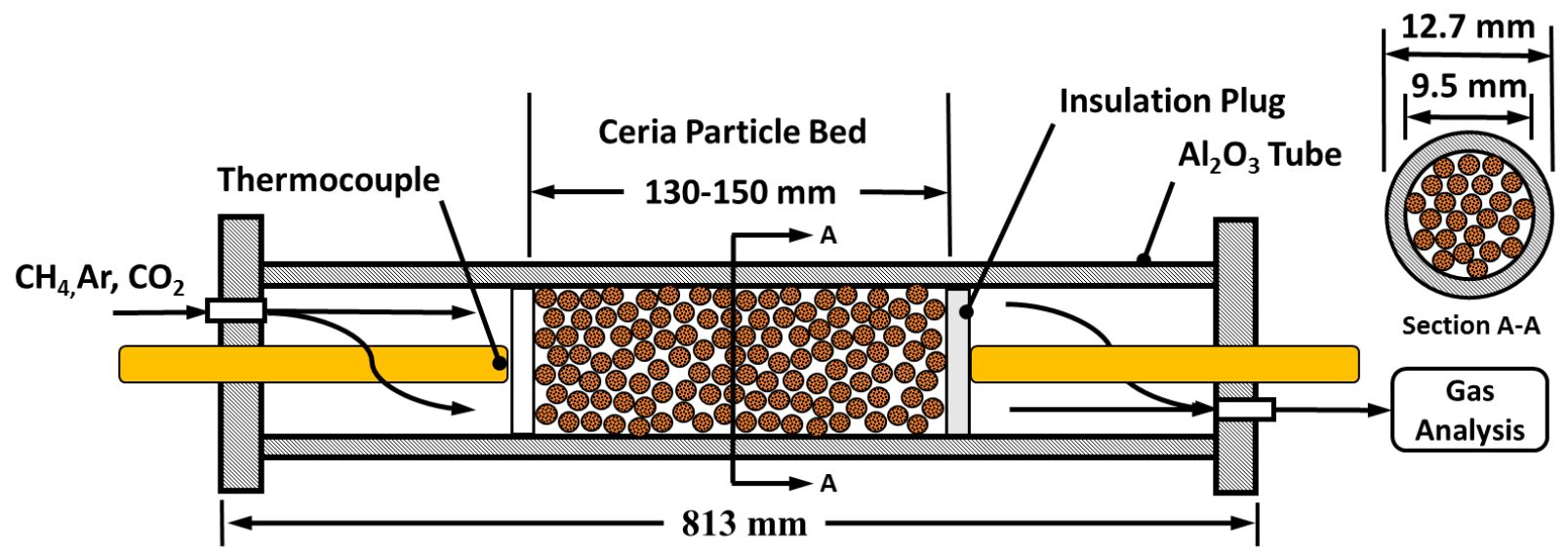

Figure 3. Sketch of the isothermal fixed bed reactor (not to scale).

\subsubsection{Data Analysis}

The reduction and oxidation rates were analyzed to determine species production rates as a function of temperature, gas flow rate, and bed-averaged ceria nonstoichiometry. The transient rates of species production are calculated by

$$
\dot{\mathrm{n}}_{\mathrm{i}}^{\prime}=\frac{\mathrm{y}_{\mathrm{i}} \dot{\mathrm{n}}_{\mathrm{TOT}}}{\mathrm{m}_{\mathrm{CeO}_{2}}}
$$

where $\dot{n}_{i}^{\prime}$ is the molar flow rate of species $i$ per unit mass of $\mathrm{CeO}_{2}$. The $\mathrm{H}_{2} \mathrm{O}$ production rate is based on the balance of hydrogen atoms.

$$
\dot{\mathrm{n}}_{\mathrm{H}_{2} \mathrm{O}}^{\prime}=2 \dot{\mathrm{n}}_{\mathrm{CH}_{4}, \mathrm{IN}}^{\prime}-\dot{\mathrm{n}}_{\mathrm{H}_{2}}^{\prime}
$$

Similarly, the rate of oxygen release/storage during reduction and oxidation is the difference in oxygen rate between the inlet and outlet gas streams. 


$$
\begin{gathered}
\dot{\mathrm{n}}_{\mathrm{O}, \mathrm{RD}}^{\prime}=\dot{\mathrm{n}}_{\mathrm{CO}}^{\prime}+2 \dot{\mathrm{n}}_{\mathrm{CO}_{2}}^{\prime}+\dot{\mathrm{n}}_{\mathrm{H}_{2} \mathrm{O}}^{\prime} \\
\dot{\mathrm{n}}_{\mathrm{O}, \mathrm{OX}}^{\prime}=2 \dot{\mathrm{n}}_{\mathrm{CO}_{2}, \mathrm{IN}}^{\prime}-\left[2 \dot{\mathrm{n}}_{\mathrm{CO}_{2}}^{\prime}+\dot{\mathrm{n}}_{\mathrm{CO}}^{\prime}\right]_{\mathrm{OUT}}
\end{gathered}
$$

The instantaneous bed-averaged nonstoichiometry during reduction and oxidation is calculated using the cumulative oxygen release and is referenced to equilibrium with the oxidizer.

$$
\begin{gathered}
\left\langle\delta\left(\mathrm{t}_{\mathrm{RD}}\right)\right\rangle=\langle\delta\rangle_{\mathrm{OX}, \mathrm{EQ}}+\mathrm{M}_{\mathrm{CeO}_{2}} \int_{0}^{\mathrm{t}_{\mathrm{RD}}} \dot{\mathrm{n}}_{\mathrm{O}, \mathrm{RD}}^{\prime} \mathrm{dt} \\
\left\langle\delta\left(\mathrm{t}_{\mathrm{OX}}\right)\right\rangle=\langle\delta\rangle_{\mathrm{OX}, \mathrm{EQ}}+\mathrm{M}_{\mathrm{CeO}_{2}} \int_{\mathrm{t}_{\mathrm{OX}}}^{\mathrm{t}_{\mathrm{OX}, \mathrm{EQ}}} \dot{\mathrm{n}}_{\mathrm{O}, \mathrm{OX}}^{\prime} \mathrm{dt}
\end{gathered}
$$

The quality of the reduction products is characterized by the $\mathrm{CH}_{4}$ conversion and selectivity towards syngas products.

$$
\begin{gathered}
\mathrm{X}_{\mathrm{CH}_{4}} \equiv 1-\frac{\dot{\mathrm{n}}_{\mathrm{CH}_{4}, \mathrm{OUT}}^{\prime}}{\dot{\mathrm{n}}_{\mathrm{CH}_{4}, \mathrm{IN}}} \\
\mathrm{S}_{\mathrm{H}_{2}} \equiv \frac{\dot{\mathrm{n}}_{\mathrm{H}_{2}}^{\prime}}{\mathrm{n}_{\mathrm{H}_{2}}^{\prime}+\dot{\mathrm{n}}_{\mathrm{H}_{2} \mathrm{O}}^{\prime}} \\
\mathrm{S}_{\mathrm{CO}} \equiv \frac{\dot{\mathrm{n}}_{\mathrm{CO}}^{\prime}}{\dot{\mathrm{n}}_{\mathrm{CO}}^{\prime}+\dot{\mathrm{n}}_{\mathrm{CO}}}
\end{gathered}
$$

Similarly for oxidation, the oxidizer conversion is defined by equation 26 .

$$
\mathrm{X}_{\mathrm{CO}_{2}} \equiv \frac{\dot{\mathrm{n}}_{\mathrm{CO}}^{\prime}}{\dot{\mathrm{n}}_{\mathrm{CO}_{2}, \mathrm{IN}}^{\prime}}
$$

Both instantaneous and cycle-averaged conversions and selectivities are reported in section 4. Instantaneous values are used to identify trends with changes in temperature, nonstoichiometry, and particle size. Cycle-averaged values are used to project efficiency. To avoid biasing the oxidizer conversion by including data as the ceria is allowed to approach equilibrium with the 
oxidizer, the cycle-averaged oxidizer conversion is evaluated for the first $95 \%$ of the change in bed-averaged nonstoichiometry.

\section{Results}

Trends in methane conversion and syngas selectivity with methane flow rate, nonstoichiometry, and temperature are presented in Section 4.1. The conversion of carbon dioxide to carbon monoxide in reaction R3 is presented in 4.2. The first law analysis of Section 2 is used to project efficiencies for the experimentally measured conversions and selectivities in Section 4.3.

\subsection{Partial Oxidation of Methane-Ceria Reduction}

The conversion of methane and selectivity toward syngas depend on the bed-averaged nonstoichiometry $-\langle\delta\rangle$, the methane flow rate, and the operating temperature. The transient species production rates for partial oxidation of methane over $5 \mathrm{~mm}$ ceria particles are plotted for methane flow rates of 1, 2.5, 5, 10 and $15 \mathrm{~mL} \mathrm{~min}^{-1} \mathrm{~g}^{-1}$ in Figure $4\left(900^{\circ} \mathrm{C}\right)$ and Figure 5 $\left(1000^{\circ} \mathrm{C}\right)$. Differences between the three cycles shown for each condition are nearly indiscernible, demonstrating the high degree of repeatability of the experiments. The transient progression of the average nonstoichiometry of the ceria bed, which determines the thermodynamic driving force for oxygen release or uptake by the ceria, is indicated along the top axis. When the flow of methane is initiated and the bed-averaged nonstoichiometry is low, i.e. when the thermodynamic impetus for oxygen release is greatest, carbon dioxide and water are produced more rapidly than carbon monoxide and hydrogen. As the reaction progresses and the nonstoichiometry increases, oxygen is released more slowly and the syngas selectivity increases. This trend describes reduction at both 900 and $1000^{\circ} \mathrm{C}$ and is consistent with the temporal trend in $\mathrm{H}_{2}$ and $\mathrm{CO}$ selectivity observed in prior work for reduction of ceria in methane at $700^{\circ} \mathrm{C}$ [14] 
and at $850^{\circ} \mathrm{C}$ [3]. For equal methane flow rates, the syngas production rates are higher at $1000^{\circ} \mathrm{C}$ than at $900^{\circ} \mathrm{C}$. For example, with $15 \mathrm{~mL} \mathrm{~min}^{-1} \mathrm{~g}^{-1} \mathrm{CH}_{4}$, the peak $\mathrm{H}_{2}$ and $\mathrm{CO}$ production rates are 3.9 and $1.9 \mathrm{~mL} \mathrm{~min}^{-1} \mathrm{~g}^{-1}$ at $1000^{\circ} \mathrm{C}$ compared to 0.7 and $0.2 \mathrm{~mL} \mathrm{~min}^{-1} \mathrm{~g}^{-1}$ at $900^{\circ} \mathrm{C}$. The syngas production rates decline with decreasing methane flow rates at both temperatures. 


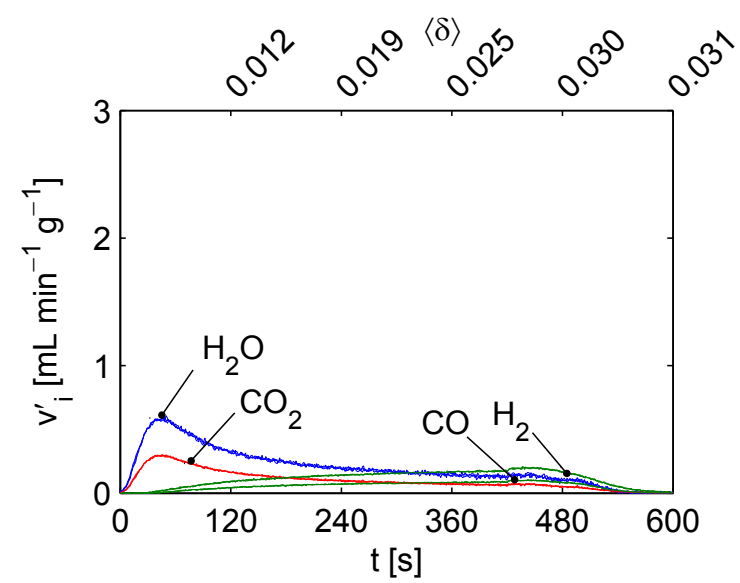

(a)

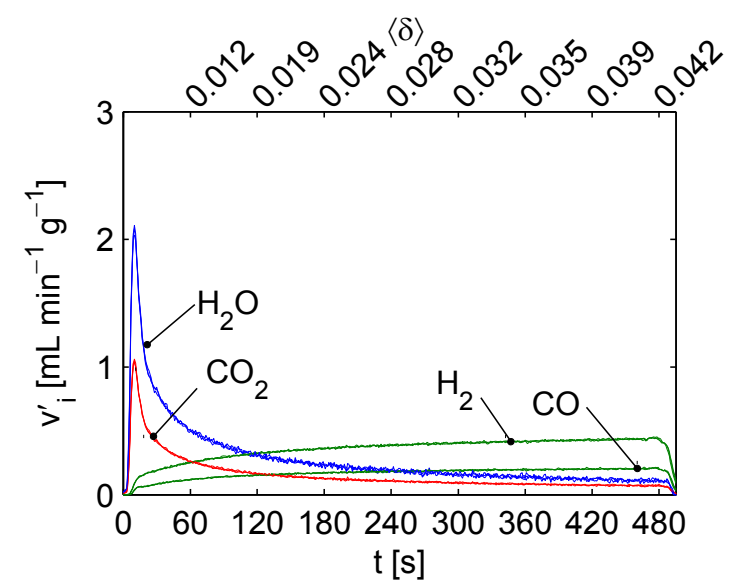

(c)

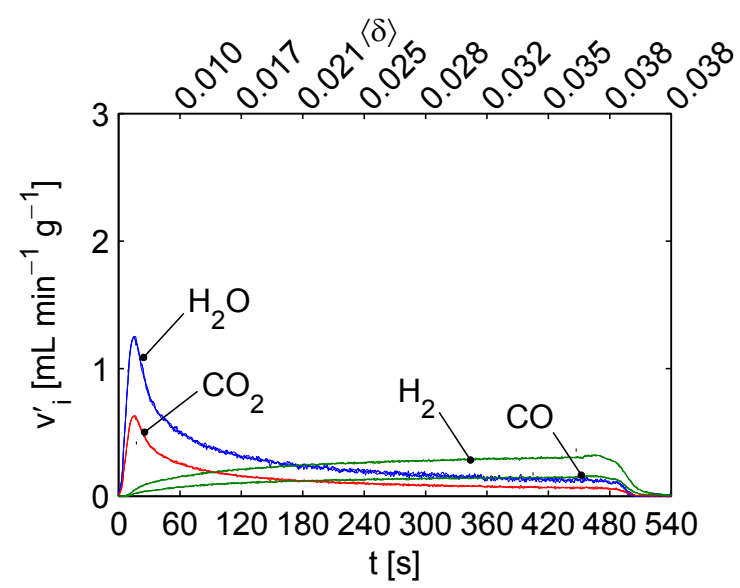

(b)

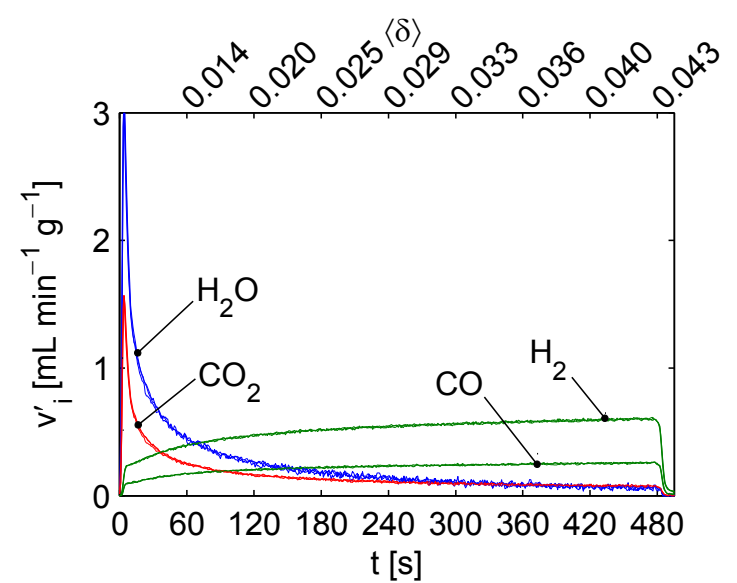

(d)

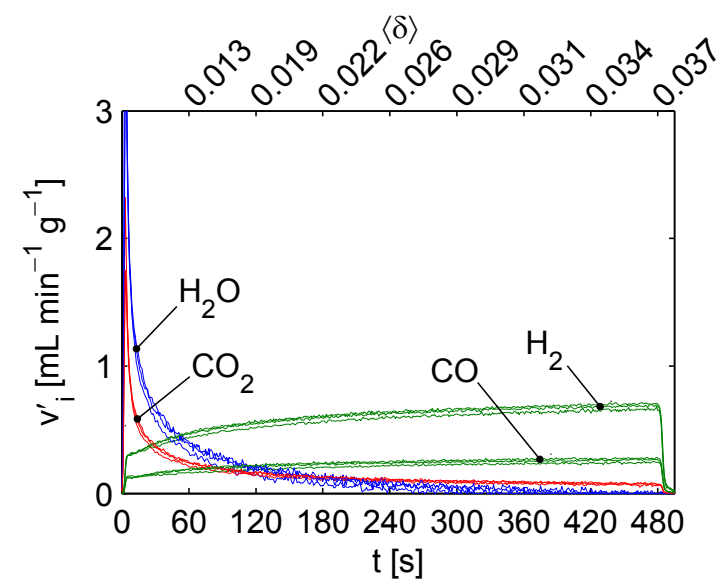

(e)

Figure 4. Effluent species flow rates for reduction of ceria at $900^{\circ} \mathrm{C}$ : (a) 1 (b) 2.5 (c) 5 (d) 10 and (e) $15 \mathrm{~mL} \mathrm{~min}^{-1} \mathrm{~g}^{-1} \mathrm{CH}_{4}$. Data are shown for three cycles at each methane flow rate to demonstrate repeatability. 


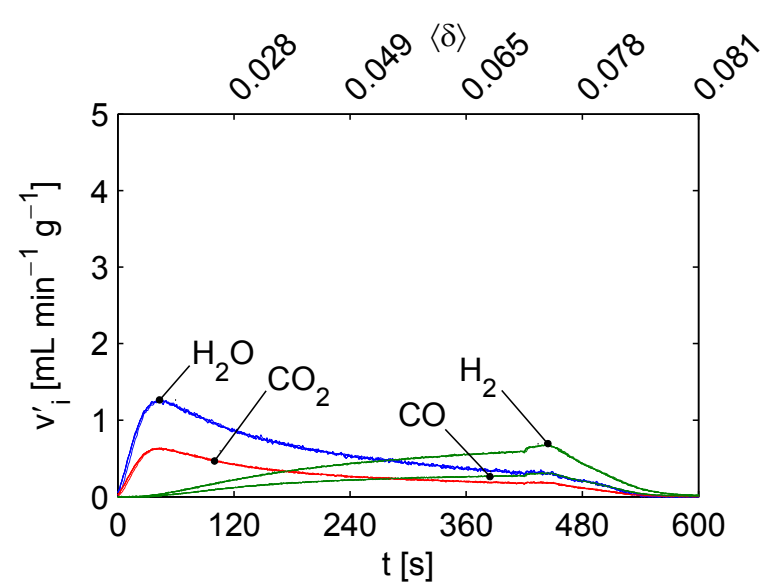

(a)

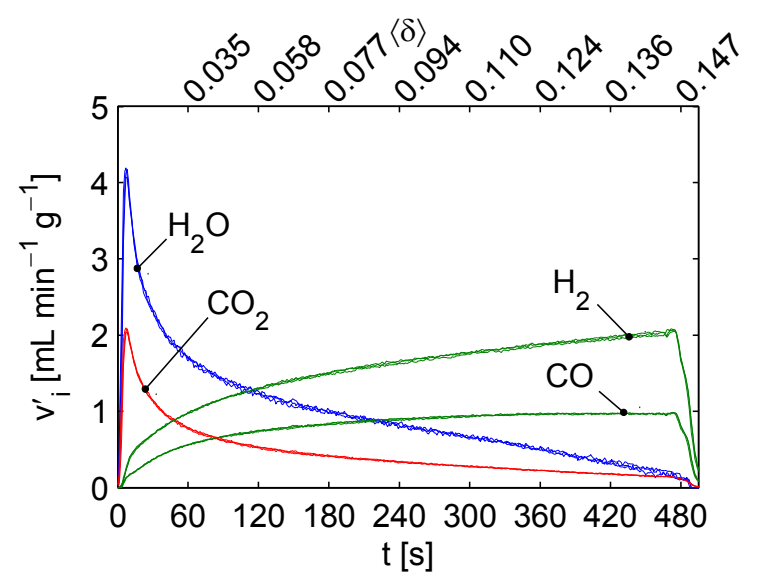

(c)

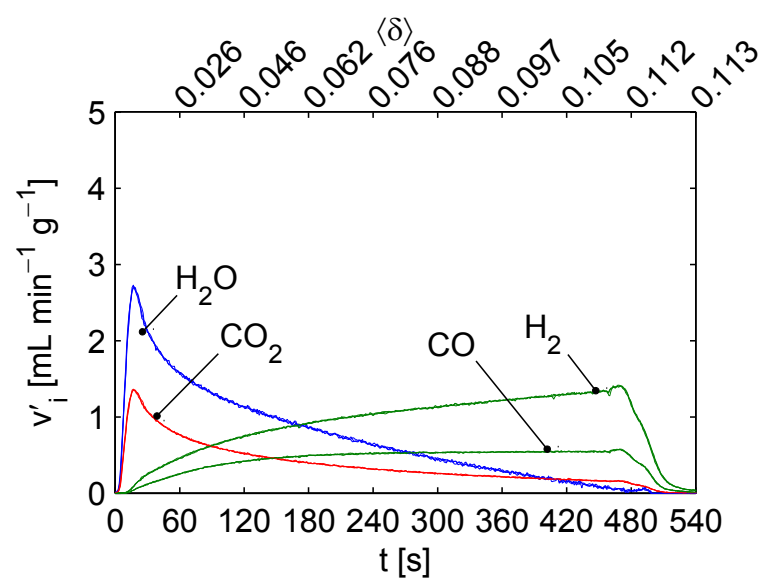

(b)

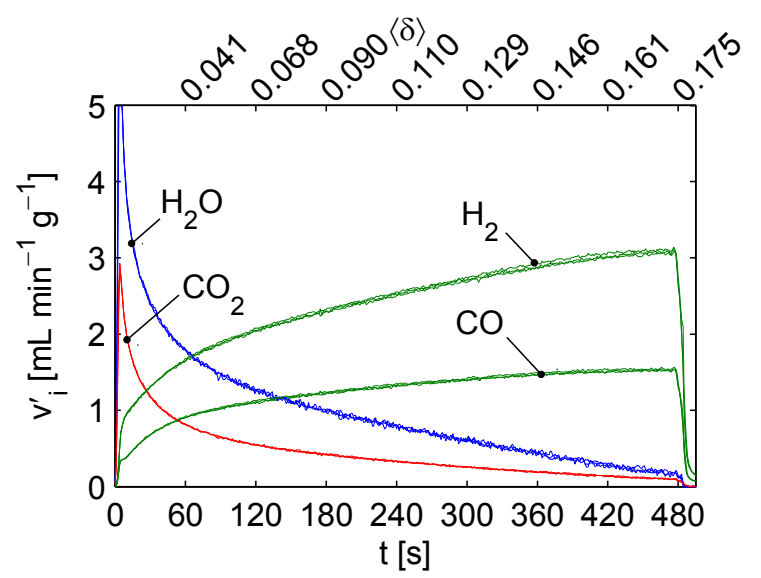

(d)

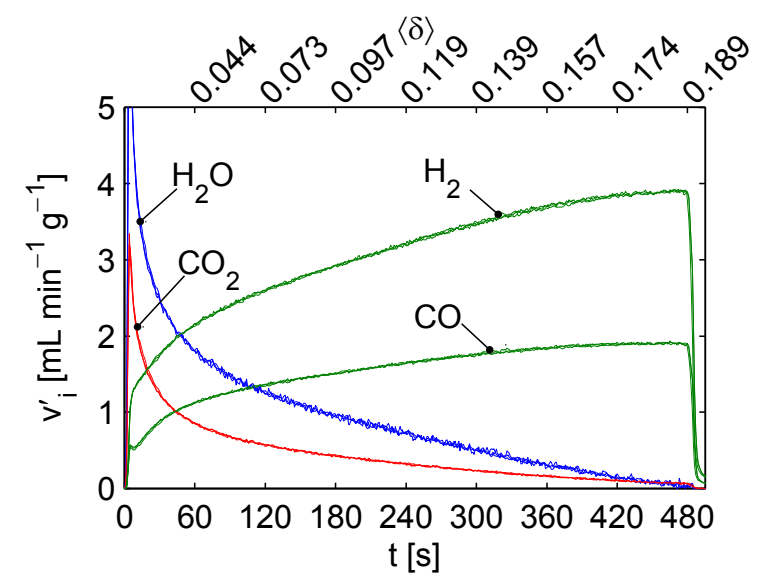

(e)

Figure 5. Effluent species flow rates for reduction of ceria at $1000^{\circ} \mathrm{C}$ : (a) 1 (b) 2.5 (c) 5 (d) 10 and (e) $15 \mathrm{~mL} \mathrm{~min}^{-1} \mathrm{~g}^{-1} \mathrm{CH}_{4}$. Data are shown for three cycles at each methane flow rate. 
The primary reduction results are the methane conversion (Figure 6), $\mathrm{H}_{2}$ selectivity (Figure 7), and CO selectivity (Figure 8). The conversion and selectivity for $1 \mathrm{~mm}$ particles (dashed curves) and 5mm particles (solid curves) are included. To aid interpretation of these data, the corresponding the $\mathrm{CH}_{4} / \mathrm{O}_{2}$ ratio, defined as the rate of $\mathrm{CH}_{4}$ supply divided by the rate of $\mathrm{O}_{2}$ release, is shown in Figure 9. The $\mathrm{CH}_{4} / \mathrm{O}_{2}$ ratio indicates which products are thermodynamically favored at the exit of the bed. For $\mathrm{CH}_{4} / \mathrm{O}_{2}=2$ at $900^{\circ} \mathrm{C}$ and $1000^{\circ} \mathrm{C}$, chemical thermodynamics predicts methane conversion and syngas selectivity greater than 97\%. For deviations from $\mathrm{CH}_{4} / \mathrm{O}_{2}=2$, the equilibrium products contain solid carbon $\left(\mathrm{CH}_{4} / \mathrm{O}_{2}>2\right)$ or significant quantities of water and carbon dioxide $\left(\mathrm{CH}_{4} / \mathrm{O}_{2}<2\right)$.

Methane conversion (Figure 6) increases with decreasing methane flow rate and increasing temperature. The highest methane conversion is attained at $1000^{\circ} \mathrm{C}$ with $1 \mathrm{~mL} \mathrm{~min}^{-1} \mathrm{~g}^{-1} \mathrm{CH}_{4}$. The instantaneous methane conversion is greater than $50 \%$ for reduction up to $\delta=0.075$, i.e. for the entire 480s reduction reaction. Methane conversion is higher at $1000^{\circ} \mathrm{C}$ than $900^{\circ} \mathrm{C}$ at each flow rate because faster rates of oxygen release provide lower $\mathrm{CH}_{4} / \mathrm{O}_{2}$ ratios. For both particle sizes and temperatures and all flow rates, the methane conversion is highest at the onset of reduction and decreases as the bed-averaged nonstoichiometry increases. The conversion is nearly constant for $\langle\delta\rangle>0.01$ at $900^{\circ} \mathrm{C}$. At $1000^{\circ} \mathrm{C}$, conversion is nearly constant for $\langle\delta\rangle>0.03$ for flow rates of 5 , 10, and $15 \mathrm{~mL} \mathrm{~min}^{-1} \mathrm{~g}^{-1} \mathrm{CH}_{4}$. The $1 \mathrm{~mm}$ (dashed curves) and $5 \mathrm{~mm}$ (solid curves) particles yield nearly the same conversion. This result suggests that methane conversion is not limited by intraparticle heat and mass transport. 


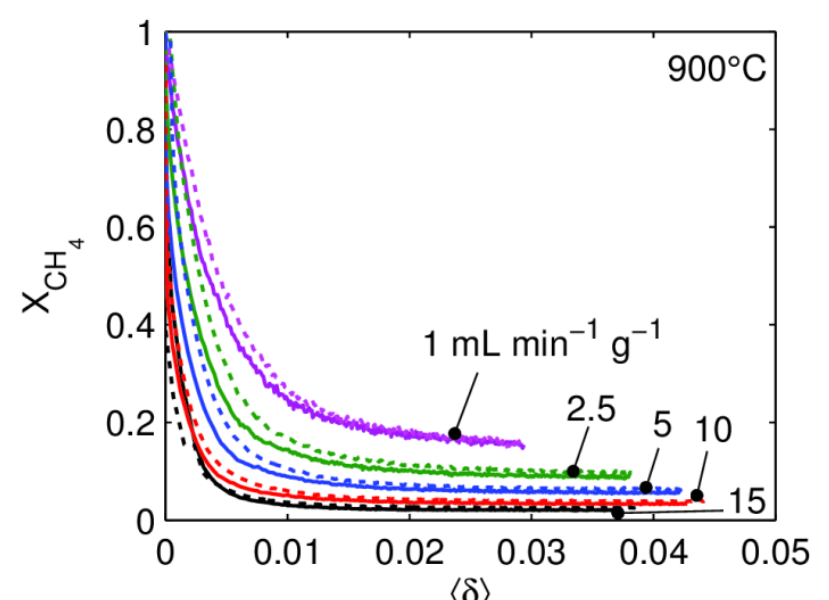

$\langle\delta\rangle$

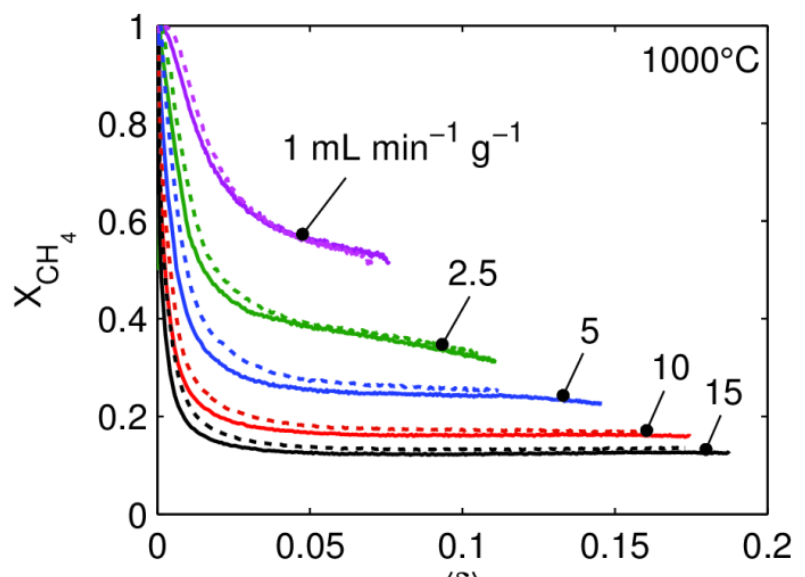

$\langle\delta\rangle$

Figure 6. Methane conversion for $1 \mathrm{~mm}$ (dashed curves) and $5 \mathrm{~mm}$ (solid curves) particles for $900^{\circ} \mathrm{C}$ (left) and $1000^{\circ} \mathrm{C}$ (right). Curves are labeled with the supply flow rate of methane.

The selectivities toward hydrogen (Figure 7) and carbon monoxide (Figure 8) exhibit a strong dependence on bed-averaged nonstoichiometry and temperature. For example, selectivity increases from $0 \%$ at $\delta=0$ to $68 \%$ for $\mathrm{H}_{2}$ and $62 \%$ for $\mathrm{CO}$ at $\delta=0.07$ for reduction in $1 \mathrm{~mL} \min ^{-1} \mathrm{~g}^{-1} \mathrm{CH}_{4}$ at $1000^{\circ} \mathrm{C}$. Selectivities exceed $75 \%$ at $\delta>0.1$ for higher flow rates. This large increase in selectivity with increasing nonstoichiometry up to $\delta=0.1$ is consistent with chemical equilibrium predictions [1]. Also consistent with equilibrium trends, selectivities are higher at $900^{\circ} \mathrm{C}$ than $1000^{\circ} \mathrm{C}$ at equivalent nonstoichiometries. Selectivities toward hydrogen and carbon monoxide generally increase with increasing methane flow rate. The hydrogen selectivity for reduction at $1000^{\circ} \mathrm{C}$ in 1 and $2.5 \mathrm{~mL} \mathrm{~min}^{-1} \mathrm{~g}^{-1} \mathrm{CH}_{4}$ departs from this trend as nonstoichiometry increases, possibly due to additional hydrogen production by methane cracking. Selectivity exhibits no significant dependence on particle size. 

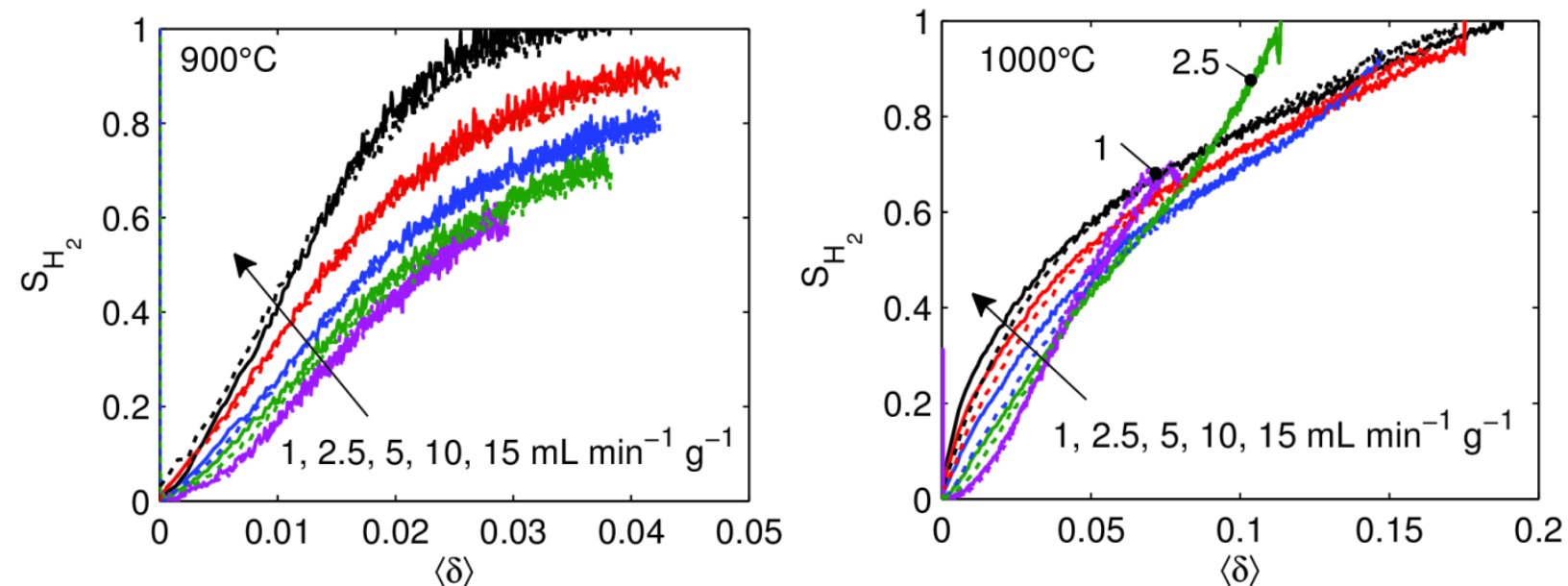

Figure 7. Hydrogen selectivity for the methane-ceria reaction at $900^{\circ} \mathrm{C}$ (left) and $1000^{\circ} \mathrm{C}$ (right). The arrow indicates the direction of increasing supply flow rate of methane.

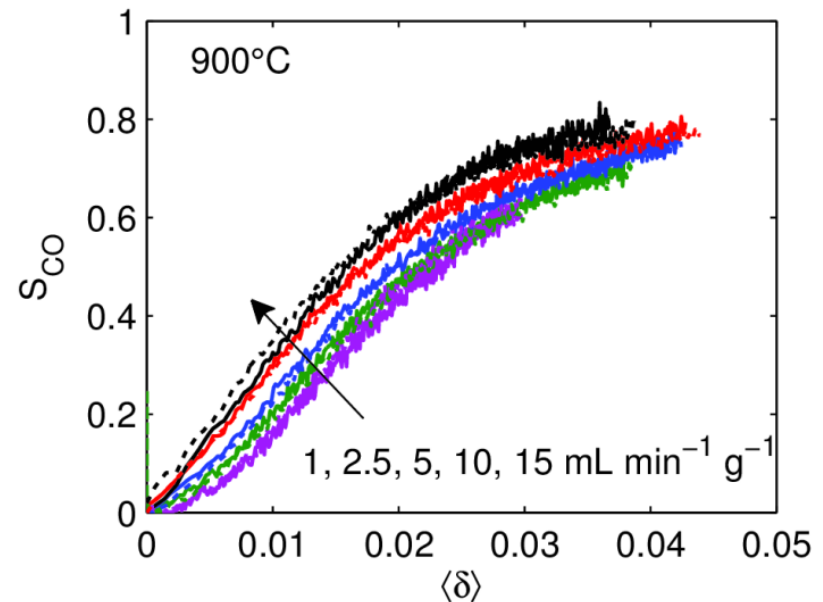

$\langle\delta\rangle$

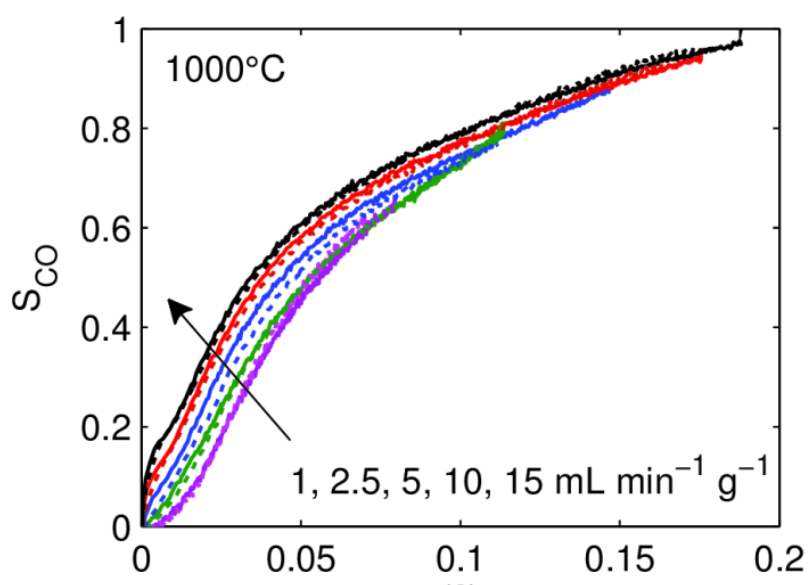

$\langle\delta\rangle$

Figure 8. Carbon monoxide selectivity at $900^{\circ} \mathrm{C}$ (left) and $1000^{\circ} \mathrm{C}$ (right). The arrow indicates the direction of increasing supply flow rate of methane.

The $\mathrm{CH}_{4} / \mathrm{O}_{2}$ ratio is shown in Figure 9 as a function of the average nonstoichiometry in the bed. To convert methane completely and obtain high selectivity toward syngas, the ratio of methane to oxygen must match the stoichiometry of reaction R1, i.e. $\mathrm{CH}_{4} / \mathrm{O}_{2}=2$. For all flow rates and both temperatures the minimum $\mathrm{CH}_{4} / \mathrm{O}_{2}$ ratio is 0.5 at the onset of reduction because the production of $\mathrm{H}_{2} \mathrm{O}$ and $\mathrm{CO}_{2}$ precedes the production of syngas. The $\mathrm{CH}_{4} / \mathrm{O}_{2}$ ratio increases with increasing nonstoichiometry as the rate of oxygen release decreases. Decreasing the 
methane flow rate or increasing the temperature results in lower $\mathrm{CH}_{4} / \mathrm{O}_{2}$ ratios at a given nonstoichiometry.

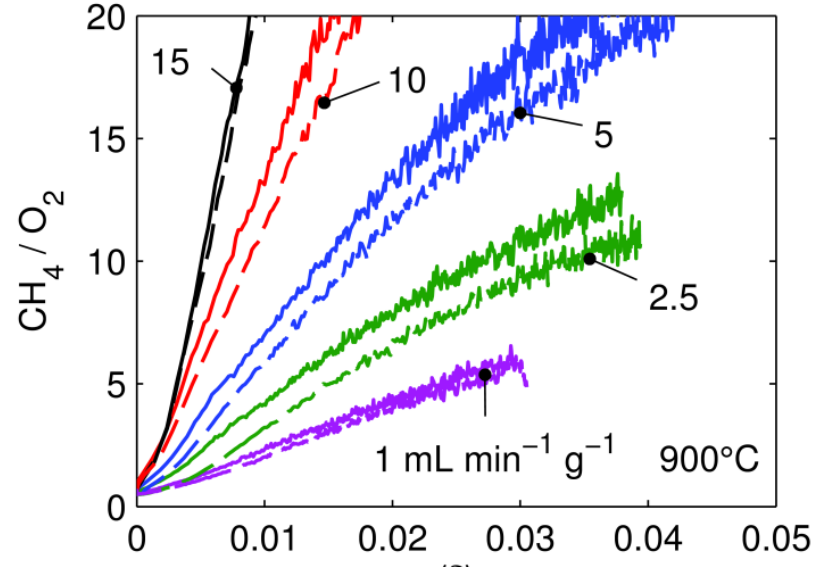

$\langle\delta\rangle$

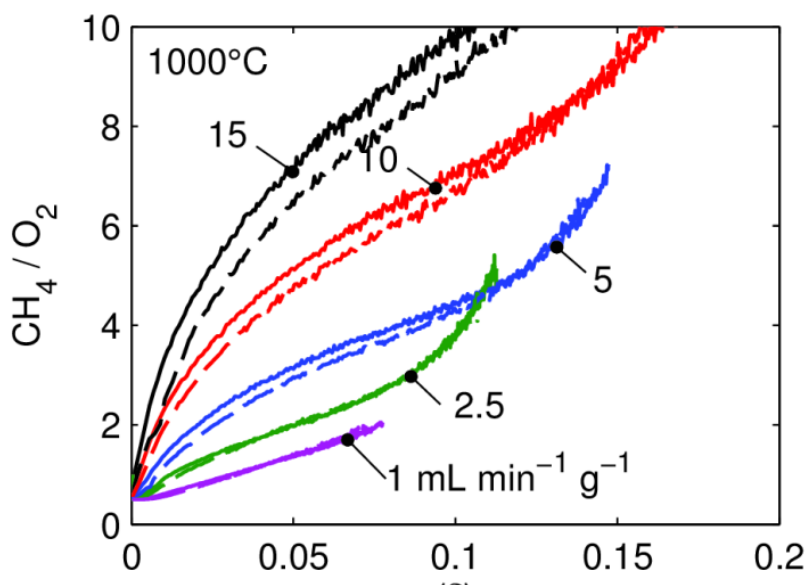

$\langle\delta\rangle$

Figure 9. $\mathrm{CH}_{4} / \mathrm{O}_{2}$ ratios at $900^{\circ} \mathrm{C}$ (left) and $1000^{\circ} \mathrm{C}$ (right). Curves are labeled with the supply flow rate of methane. The vertical scale is selected to aid in the interpretation of the data and depends on temperature.

In the limit of infinitely fast transport and kinetics, we would expect an equilibrium product composition and the $\mathrm{CH}_{4} / \mathrm{O}_{2}$ ratio alone would determine the product mixture. The bed-averaged nonstoichiometry at which $\mathrm{CH}_{4} / \mathrm{O}_{2}=2$ and the corresponding methane conversion and syngas selectivities are listed in Table 2. The measured methane conversion and syngas selectivity are lower than predicted by chemical equilibrium ( $>97 \%$ ) for $\mathrm{CH}_{4} / \mathrm{O}_{2}=2$. Methane conversion is the same (26-27\%) for all flow rates at $\mathrm{CH}_{4} / \mathrm{O}_{2}=2$ and $900^{\circ} \mathrm{C}$, but increases from near $30 \%$ to $51 \%$ as the flow rate is decreased at $1000^{\circ} \mathrm{C}$. As the methane flow rate is decreased, both the nonstoichiometry at which $\mathrm{CH}_{4} / \mathrm{O}_{2}=2$ and the selectivities increase. For a decrease in methane flow rate from 15 to $1 \mathrm{~mL} \mathrm{~min}^{-1} \mathrm{~g}^{-1}$ at $1000^{\circ} \mathrm{C}$, the nonstoichiometry increases from 0.004 to 0.076 and selectivities increase from $14 \%$ to $70 \%\left(\mathrm{H}_{2}\right)$ and $15 \%$ to $63 \%(\mathrm{CO})$. 
Table 2. Nonstoichiometry, methane conversion, and syngas selectivity at which $\mathrm{CH}_{4} / \mathrm{O}_{2}=2$ for reduction of $5 \mathrm{~mm}$ particles at 900 and $1000^{\circ} \mathrm{C}$.

\begin{tabular}{|c|c|c|c|c|}
\hline $\begin{array}{l}\text { Methane } \\
\text { Flow Rate }\end{array}$ & $\begin{array}{l}\text { Bed-averaged } \\
\text { Nonstoichiometry }\end{array}$ & $\begin{array}{l}\text { Methane } \\
\text { Conversion }\end{array}$ & $\begin{array}{l}\text { Hydrogen } \\
\text { Selectivity }\end{array}$ & $\begin{array}{l}\text { Carbon } \\
\text { Monoxide } \\
\text { Selectivity }\end{array}$ \\
\hline$v_{C H_{4}}^{\prime}$ & $\langle\delta\rangle_{2: 1}$ & $\mathrm{X}_{\mathrm{CH}_{4}}$ & $S_{H_{2}}$ & $S_{C O}$ \\
\hline \multicolumn{5}{|c|}{$900^{\circ} \mathrm{C}$} \\
\hline 1 & 0.008 & $27 \%$ & $14 \%$ & $11 \%$ \\
\hline 2.5 & 0.005 & $26 \%$ & $6 \%$ & $8 \%$ \\
\hline 5 & 0.003 & $26 \%$ & $6 \%$ & $5 \%$ \\
\hline 10 & 0.001 & $26 \%$ & $5 \%$ & $4 \%$ \\
\hline 15 & 0.001 & $27 \%$ & $4 \%$ & $3 \%$ \\
\hline \multicolumn{5}{|c|}{$1000^{\circ} \mathrm{C}$} \\
\hline 1 & 0.076 & $51 \%$ & $70 \%$ & $63 \%$ \\
\hline 2.5 & 0.051 & $38 \%$ & $44 \%$ & $49 \%$ \\
\hline 5 & 0.021 & $31 \%$ & $24 \%$ & $26 \%$ \\
\hline 10 & 0.008 & $28 \%$ & $18 \%$ & $15 \%$ \\
\hline 15 & 0.004 & $30 \%$ & $14 \%$ & $15 \%$ \\
\hline
\end{tabular}

\subsection{Oxidation}

Figure 10 shows conversion of carbon dioxide versus nonstoichiometry at 900 and $1000^{\circ} \mathrm{C}$. The flow rate of methane during reduction is indicated on each curve. The oxidizer flow rate is $10 \mathrm{ml} \mathrm{min} \mathrm{g}^{-1}$. The initial nonstoichiometry of the bed increases with increasing temperature and methane flow rate. The fact that the curves do not collapse indicates that the nonstoichiometry is not uniform in the bed after reduction. In this case, the oxidizer conversion depends on the spatial distribution of the nonstoichiometry. Though conversion is always higher at $1000^{\circ} \mathrm{C}$, the trends are the same at both temperatures. For brevity, quantities are given only for oxidation at $1000^{\circ} \mathrm{C}$ in the following discussion. For oxidation following reduction with 15 $\mathrm{ml} \mathrm{min}^{-1} \mathrm{~g}^{-1} \mathrm{CH}_{4}$, the oxidizer is almost completely converted to fuel, $\mathrm{X}_{\mathrm{CO}_{2}}=0.96$, for $\langle\delta\rangle>0.06$. Following reduction with $1 \mathrm{ml} \mathrm{min}{ }^{-1} \mathrm{~g}^{-1} \mathrm{CH}_{4}$, the conversion reaches only 0.72 . Consistent with the observation for reduction, the particle size has negligible impact on oxidizer conversion for 
$\langle\delta\rangle>0.05$. The oxidizer conversion decreases as the nonstoichiometry decreases below $\langle\delta\rangle=0.05$ for the 5mm particles, consistent with chemical thermodynamic predictions for oxidizer conversion. The decrease in oxidizer conversion for $1 \mathrm{~mm}$ particles occurs at slightly lower nonstoichiometry, $\langle\delta\rangle \approx 0.03$, providing enhanced oxidizer conversion over a small nonstoichiometry range.
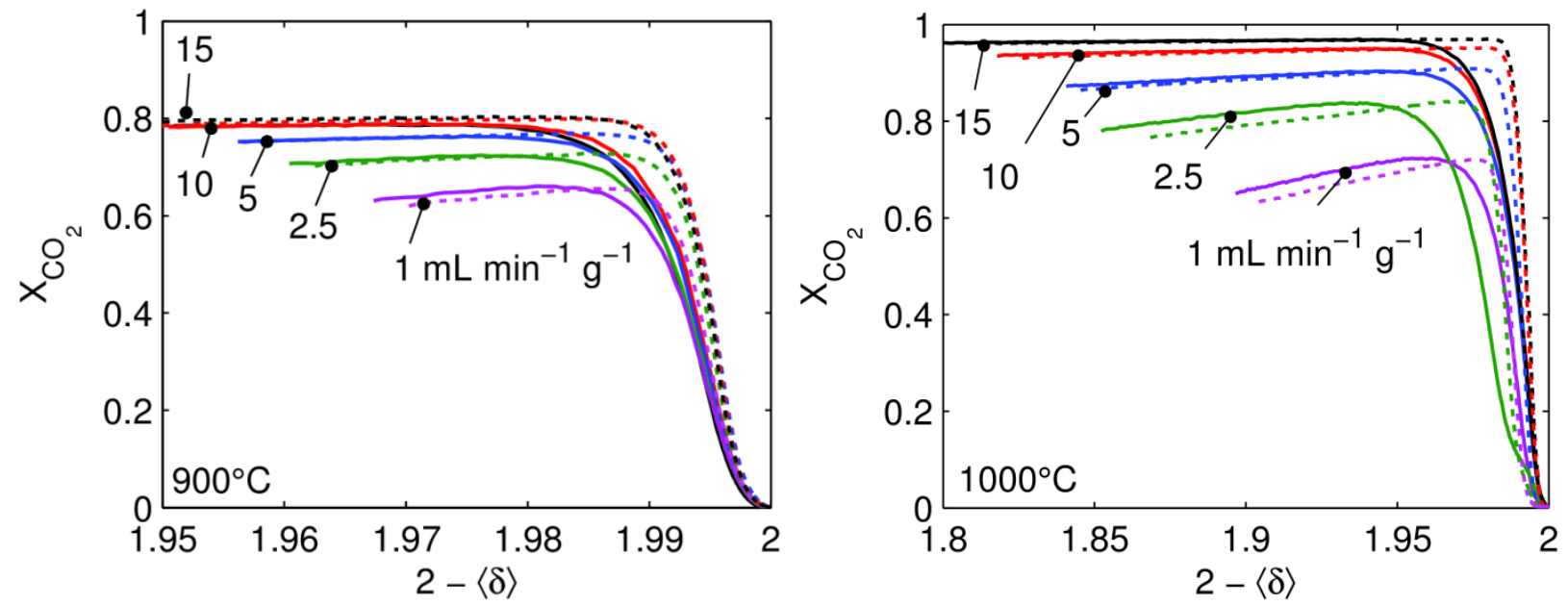

Figure 10. Carbon dioxide conversion for oxidation in $10 \mathrm{~mL} \mathrm{~min}^{-1} \mathrm{~g}^{-1} \mathrm{CO}_{2}$ at $900^{\circ} \mathrm{C}$ (left) and $1000^{\circ} \mathrm{C}$ (right). Curves are labeled with the supply flow rate of methane during reduction. Conversion during oxidation is expressed versus $2-\langle\delta\rangle$ to preserve the direction of time progression from left to right.

\subsection{Projected Solar-to-fuel Efficiency}

Figure 11 shows the projected solar-to-fuel thermal efficiency based on the measured methane conversion, syngas selectivity, and oxidizer conversion. The efficiency is plotted versus the methane flow rate for 900 and $1000^{\circ} \mathrm{C}$ and both particle sizes. Table 3 summarizes the cycleaveraged conversions and selectivities at $1000^{\circ} \mathrm{C}$ measured for $5 \mathrm{~mm}$ particles to show competing trends of conversion and selectivity with increasing methane flow rate. Within the size range considered, particle size has negligible impact. Operation at the $1000^{\circ} \mathrm{C}$ yields higher efficiency than at $900^{\circ} \mathrm{C}$, as anticipated from the observed higher conversion of both methane and oxidizer at $1000^{\circ} \mathrm{C}$. The increased cycle-averaged selectivities at $1000^{\circ} \mathrm{C}$ compared to $900^{\circ} \mathrm{C}$, which also 
contribute to higher efficiency, are attributed to reducing to larger nonstoichiometries. The highest efficiency at $900^{\circ} \mathrm{C}$ is $15 \%$ for reduction in $2.5 \mathrm{~mL} \mathrm{~min}^{-1} \mathrm{~g}^{-1} \mathrm{CH}_{4}$. The highest projected efficiency at $1000^{\circ} \mathrm{C}$ is $27 \%$ for reduction in $5 \mathrm{~mL} \mathrm{~min}^{-1} \mathrm{~g}^{-1} \mathrm{CH}_{4}$. For this condition, the methane conversion is $25 \%$, selectivities are $62 \%\left(\mathrm{H}_{2}\right)$ and $66 \%(\mathrm{CO})$, and the oxidizer conversion is 84\%. Syngas selectivity and oxidizer conversion are higher for higher methane flow rates, but the efficiency is lower because of lower methane conversion. Conversely, methane conversion is higher at lower methane flow rates, but the projected efficiency is lower due to lower syngas selectivity and oxidizer conversion. As shown in Table 3, methane conversion increases from $13 \%$ for reduction in $15 \mathrm{~mL} \mathrm{~min}^{-1} \mathrm{~g}^{-1}$ to $60 \%$ in $1 \mathrm{~mL} \mathrm{~min}^{-1} \mathrm{~g}^{-1}$. For the same change in methane flow rate, the cycle-averaged selectivities decrease from $78 \%$ to $39 \%(\mathrm{CO})$ and $77 \%$ to $40 \%\left(\mathrm{H}_{2}\right)$ and the oxidizer conversion decreases from $93 \%$ to $48 \%$.

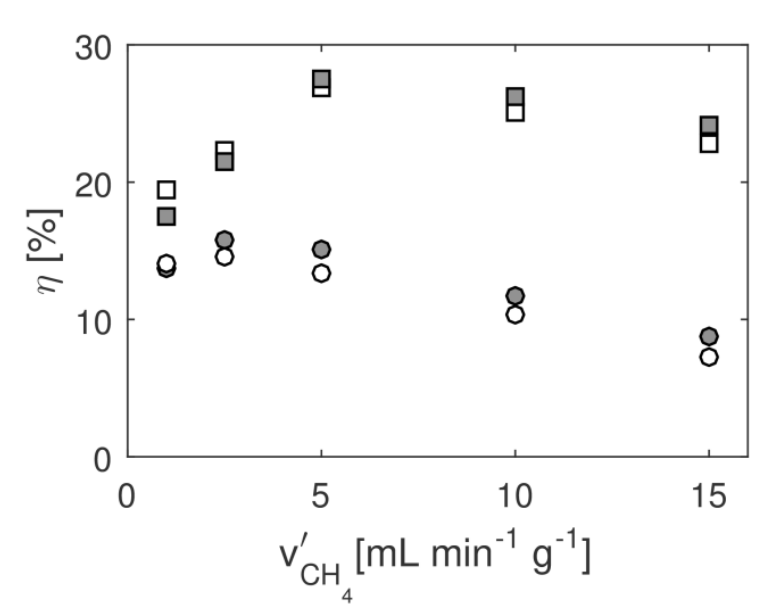

Figure 11. Efficiency as a function of methane flow rate for measured conversions and selectivities at $900^{\circ} \mathrm{C}$ (circles) and at $1^{1000^{\circ}} \mathrm{C}$ (squares) with $5 \mathrm{~mm}$ (open symbols) and $1 \mathrm{~mm}$ (filled symbols) particles. 
Table 3. Conversion, selectivity and efficiency for cycles at 900 and $1000^{\circ} \mathrm{C}$ with $5 \mathrm{~mm}$ particles.

\begin{tabular}{|c|c|c|c|c|c|}
\hline $\begin{array}{c}\text { Methane } \\
\text { Flow Rate }\end{array}$ & $\begin{array}{c}\text { Methane } \\
\text { Conversion }\end{array}$ & $\begin{array}{l}\text { Hydrogen } \\
\text { Selectivity }\end{array}$ & $\begin{array}{c}\text { Carbon } \\
\text { Monoxide } \\
\text { Selectivity }\end{array}$ & $\begin{array}{c}\text { Oxidizer } \\
\text { Conversion }\end{array}$ & Efficiency \\
\hline $\begin{array}{c}\boldsymbol{v}_{\boldsymbol{C H}_{4}}^{\prime} \\
{\left[\mathrm{mL} \mathrm{min}^{-1} \mathrm{~g}^{-1}\right]}\end{array}$ & $\begin{array}{c}\mathrm{X}_{\mathrm{CH}_{4}} \\
{[\%]}\end{array}$ & $\begin{array}{l}S_{\mathrm{H}_{2}} \\
{[\%]}\end{array}$ & $\begin{array}{l}S_{C O} \\
{[\%]}\end{array}$ & $\begin{array}{c}\boldsymbol{X}_{\mathrm{CO}_{2}} \\
{[\%]}\end{array}$ & $\begin{array}{c}\boldsymbol{\eta} \\
{[\%]}\end{array}$ \\
\hline \multicolumn{6}{|c|}{$900^{\circ} \mathrm{C}$} \\
\hline 1 & 20 & 36 & 37 & 31 & 14 \\
\hline 2.5 & 11 & 47 & 47 & 40 & 15 \\
\hline 5 & 7 & 56 & 53 & 50 & 13 \\
\hline 10 & 4 & 68 & 59 & 57 & 10 \\
\hline 15 & 2 & 78 & 59 & 49 & 7 \\
\hline \multicolumn{6}{|c|}{$1000^{\circ} \mathrm{C}$} \\
\hline 1 & 60 & 40 & 39 & 48 & 19 \\
\hline 2.5 & 37 & 56 & 54 & 56 & 22 \\
\hline 5 & 25 & 62 & 66 & 84 & 27 \\
\hline 10 & 17 & 71 & 74 & 90 & 25 \\
\hline 15 & 13 & 77 & 78 & 93 & 23 \\
\hline
\end{tabular}

\section{Conclusions}

This study explores a process to produce syngas using concentrated solar energy as the source of heat. The process couples the partial oxidation of methane and the cerium dioxide (ceria) redox cycle for water or $\mathrm{CO}_{2}$ splitting. As presented by Krenzke and Davidson in a prior thermodynamic analysis, the coupled process offers substantial benefits compared to the solar thermochemical ceria redox cycle, which has been the focus of recent efforts to split water and carbon dioxide [1]. Assuming an equilibrium model for the chemical reactions, the solar to fuel efficiency for operating at $950^{\circ} \mathrm{C}$ could reach $40 \%$. The present study moves beyond the theoretical thermodynamic projection of efficiency to more realistic projections based on measured reaction products for cycling in a fixed bed reactor. The conversion of methane, selectivity toward syngas, and oxidizer conversion are the key metrics impacting efficiency. 
A parametric study of the impact of temperature and methane flow rate on conversion and selectivities of partial oxidation of methane and $\mathrm{CO}_{2}$ splitting over a bed of 1-5 mm porous ceria particles heated in an electric furnace is presented for cycling at 900 and $1000^{\circ} \mathrm{C}$. Within the considered size range, particle size is found to have negligible impact on conversion, selectivity, and efficiency. Increasing the temperature from 900 to $1000^{\circ} \mathrm{C}$ increases the conversion of methane and oxidizer, while maintaining or improving the cycle-averaged selectivity toward syngas. Operation at $1100^{\circ} \mathrm{C}$ leads to methane cracking, indicating that $1000^{\circ} \mathrm{C}$ is near the upper limit on operating temperature for the cycle.

The cycle-averaged conversion of methane is increased from $13 \%$ to $60 \%$ by decreasing the methane flow rate from $15 \mathrm{~mL} \mathrm{~min}^{-1} \mathrm{~g}^{-1}$ to $1 \mathrm{~mL} \mathrm{~min}^{-1} \mathrm{~g}^{-1}$ at $1000^{\circ} \mathrm{C}$. The increase in methane conversion is attributed to more favorable $\mathrm{CH}_{4} / \mathrm{O}_{2}$ ratios attained by closer matching of the rate of methane supply to the rate of oxygen release. However, the improvement in methane conversion with decreasing methane flow rate is accompanied by a decrease in syngas selectivities from $77 \%$ to $40 \%$ and in the conversion of carbon dioxide from $93 \%$ to $48 \%$. This is the first time the trade-off between achieving high methane conversion and high oxidizer conversion has been observed for the cycle. Temporal trends in conversion and selectivity are attributed to changes in the bed-averaged nonstoichiometry. Both syngas selectivity and oxidizer conversion increase with increasing nonstoichiometry.

The sensitivity of efficiency to methane flow rate reflects the compromise between achieving high cycle-averaged methane conversion or high syngas selectivity and oxidizer conversion. The projected solar-to-fuel thermal efficiency based on the measured reaction products reaches $27 \%$ for cycling at $1000^{\circ} \mathrm{C}$ with reduction in methane at $5 \mathrm{~mL} \mathrm{~min}^{-1} \mathrm{~g}^{-1}$ and oxidation by $\mathrm{CO}_{2}$ at a

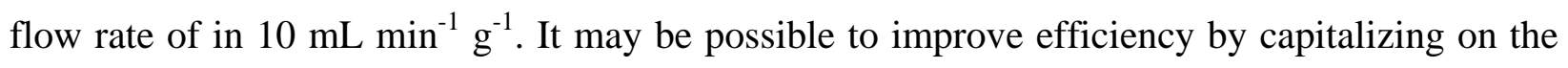


observed dependence of selectivity and oxidizer conversion on nonstoichiometry. Even without improvement, the measured performance demonstrates the potential of the partial oxidation of methane-ceria redox cycle to produce syngas efficiently using concentrated solar energy.

\section{Nomenclature}

C Solar concentration ratio

I Direct normal irradiance, $1000 \mathrm{~W} \mathrm{~m}^{-2}$

$\mathrm{m}_{\mathrm{CeO}_{2}} \quad$ Mass of ceria, g

$\mathrm{M}_{\mathrm{CeO}_{2}} \quad$ Molar mass of ceria, $\mathrm{g} \mathrm{mol}^{-1}$

$\dot{\mathrm{n}}^{\prime} \quad$ Mass specific molar flow rate, $\mathrm{mol} \mathrm{s}^{-1} \mathrm{~g}^{-1}$

$\mathrm{p} \quad$ Pressure, $\mathrm{kPa}$

Q Heat, J

$\mathrm{R} \quad$ Ideal gas constant, $8.314 \mathrm{~J} \mathrm{~mol}^{-1} \mathrm{~K}^{-1}$

$\mathrm{S}_{\mathrm{CO}} \quad$ Carbon monoxide selectivity

$\mathrm{S}_{\mathrm{H}_{2}} \quad$ Hydrogen selectivity

$\mathrm{t} \quad$ Time, $\mathrm{s}$

$\mathrm{T}$ Temperature of ceria bed, $\mathrm{K}$

W Work, J

$\mathrm{X}_{\mathrm{CH}_{4}} \quad$ Methane conversion

$\mathrm{X}_{\mathrm{CO}_{2}} \quad$ Carbon dioxide conversion

$\mathrm{y} \quad$ Mole fraction

$\Delta \delta \quad$ Change in ceria nonstoichiometry

$\langle\delta\rangle \quad$ Bed-averaged ceria nonstoichiometry

$\sigma \quad$ Stefan-Boltzmann constant, $\mathrm{W} \mathrm{m}^{-2} \mathrm{~K}^{-1}$

Subscript

EQ Equilibrium state

i Gas species i

IN Inlet of the reactive bed

OUT Outlet of the reactive bed

OX Oxidation

RD Reduction

SOL Solar

TOT Total 


\section{Acknowledgements}

The authors thank Dr. Adam Gladen at the University of Minnesota for the analysis of SEM images to determine fiber geometry and for the reported data on particle surface area and porosity. We gratefully acknowledge the financial support by the National Science Foundation through grant number EFRI-1038307 and through fellowships to Peter Krenzke and Jesse Fosheim from the Graduate Research Fellowship Program. Parts of this work were carried out in the Characterization Facility, University of Minnesota, which receives partial support from NSF through the MRSEC program. Additional financial support from the University of Minnesota was provided by a Doctoral Dissertation Fellowship to Peter Krenzke.

\section{References}

[1] Krenzke PT, Davidson JH. Thermodynamic analysis of syngas production via the solar thermochemical cerium oxide redox cycle with methane-driven reduction. Energy and Fuels 2014;28:4088-95. doi:10.1021/ef500610n.

[2] Li K, Wang H, Wei Y, Yan D. Direct conversion of methane to synthesis gas using lattice oxygen of CeO2-Fe2O3 complex oxides. Chem Eng J 2010;156:512-8. doi:10.1016/j.cej.2009.04.038.

[3] Li K, Wang H, Wei Y, Yan D. Syngas production from methane and air via a redox process using Ce-Fe mixed oxides as oxygen carriers. Appl Catal B Environ 2010;97:36172.

[4] Li K, Wang H, Wei Y, Yan D. Transformation of methane into synthesis gas using the redox property of Ce-Fe mixed oxides: Effect of calcination temperature. Int J Hydrogen Energy 2011;36:3471-82. doi:10.1016/j.ijhydene.2010.12.038.

[5] Zhu X, Wei Y, Wang H, Li K. Ce-Fe oxygen carriers for chemical-looping steam methane reforming. Int J Hydrogen Energy 2013;38:4492-501. doi:10.1016/j.ijhydene.2013.01.115.

[6] Gu Z, Li K, Wang H, Wei Y, Yan D, Qiao T. Syngas production from methane over CeO2-Fe2O3 mixed oxides using a chemical-looping method. Kinet Catal 2013;54:32633. doi:10.1134/S002315841303004X.

[7] Sang X-L, Li K-Z, Wang H, Wei Y-G. Selective oxidation of methane and carbon deposition over $\mathrm{Fe} 2 \mathrm{O} 3 / \mathrm{Ce} 1-\mathrm{x} \quad \mathrm{Zr} \quad \mathrm{x} \quad \mathrm{O} 2$ oxides. Rare $\mathrm{Met}$ 2014;33:230-8. 
doi:10.1007/s12598-013-0173-3.

[8] Otsuka K, Wang Y, Nakamura M. Direct conversion of methane to synthesis gas through gas-solid reaction using $\mathrm{CeO} 2-\mathrm{ZrO} 2$ solid solution at moderate temperature. Appl Catal A Gen 1999;183:317-24.

[9] Pantu P, Kim K, Gavalas GR. Methane partial oxidation on Pt / CeO2 - ZrO2 in the absence of gaseous oxygen. Appl Catal A Gen 2000;193:203-14. doi:10.1016/S0926860X(99)00429-9.

[10] Zheng Y, Wei Y, Li K, Zhu X, Wang H, Wang Y. Chemical-looping steam methane reforming over macroporous $\mathrm{CeO} 2-\mathrm{ZrO} 2$ solid solution: Effect of calcination temperature. Int J Hydrogen Energy 2014;39:13361-8. doi:10.1016/j.ijhydene.2014.04.116.

[11] Otsuka K, Wang Y, Sunada E, Yamanaka I. Direct Partial Oxidation of Methane to Synthesis Gas by Cerium Oxide. J Catal 1998;175:152-60. doi:10.1006/jcat.1998.1985.

[12] Otsuka K, Sunada E, Ushiyama T, Yamanaka I. The production of synthesis gas by the redox of cerium oxide. Stud Surf Sci ... 1997;107:531-6.

[13] Zhu X, Li K, Wei Y, Wang H, Sun L. Chemical-Looping Steam Methane Reforming over a CeO2-Fe2O3 Oxygen Carrier: Evolution of Its Structure and Reducibility. Energy \& Fuels 2014;760.

[14] Fathi M, Bjorgum E, Viig T, Rokstad O. O. Partial oxidation of methane to synthesis gas: Elimination of gas phase oxygen. Catal Today 2000;63:489-97. doi:10.1016/S09205861(00)00495-8.

[15] Venstrom LJ, De Smith RM, Hao Y, Haile SM, Davidson JH. Efficient Splitting of CO2 in an Isothermal Redox Cycle Based on Ceria. Energy \& Fuels 2014;28:2732-42. doi:10.1021/ef402492e.

[16] Petkovich ND, Rudisill SG, Venstrom LJ, Boman DB, Davidson JH, Stein A. Control of Heterogeneity in Nanostructured Ce 1-x Zr x O 2 Binary Oxides for Enhanced Thermal Stability and Water Splitting Activity. J Phys Chem C 2011;115:21022-33. doi:10.1021/jp2071315.

[17] Venstrom LJ, Petkovich N, Rudisill S, Stein A, Davidson JH. The Effects of Morphology on the Oxidation of Ceria by Water and Carbon Dioxide. J Sol Energy Eng 2012;134:011005. doi:10.1115/1.4005119.

[18] Rudisill SG, Venstrom LJ, Petkovich ND, Quan T, Hein N, Boman DB, et al. Enhanced Oxidation Kinetics in Thermochemical Cycling of CeO 2 through Templated Porosity. J Phys Chem C 2013;117:1692-700. doi:10.1021/jp309247c.

[19] Ackermann S, Sauvin L, Castiglioni R, Rupp JLM, Scheffe JR, Steinfeld A. Kinetics of $\mathrm{CO}_{2}$ Reduction Over Nonstoichiometric Ceria. J Phys Chem C 2015:150621102458005. doi:10.1021/acs.jpcc.5b03464.

[20] Schunk LO, Lipiński W, Steinfeld a. Heat transfer model of a solar receiver-reactor for the thermal dissociation of $\mathrm{ZnO}$-Experimental validation at $10 \mathrm{~kW}$ and scale-up to $1 \mathrm{MW}$. Chem Eng J 2009;150:502-8. doi:10.1016/j.cej.2009.03.012. 
[21] Mancini T, Heller P, Butler B, Osborn B, Schiel W, Goldberg V, et al. Dish-Stirling Systems: An Overview of Development and Status. J Sol Energy Eng 2003;125:135. doi:10.1115/1.1562634.

[22] Moran MJ, Shapiro HN, Boettner DD, Bailey M. Fundamentals of Engineering Thermodynamics. John Wiley \& Sons; 2010.

[23] House KZK, Baclig AAC, Ranjan M, van Nierop EA, Wilcox J, Herzog HJ. Economic and energetic analysis of capturing $\mathrm{CO}_{2}$ from ambient air. Proc Natl Acad Sci U S A 2011;108:20428-33. doi:10.1073/pnas.1012253108//DCSupplemental.www.pnas.org/cgi/doi/10.1073/pnas.1012253108.

[24] Venstrom LJ, De Smith RM, Hao Y, Haile SM, Davidson JH. Efficient Splitting of $\mathrm{CO}_{2}$ in an Isothermal Redox Cycle Based on Ceria. Energy \& Fuels 2014;28:2732-42. doi:10.1021/ef402492e. 